Пустовіт В. Ю., доктор філолологічних наук, професор кафедри української мови та літератури Східноукраїнського національного університету імені Володимира Даля (м. Сєвєродонецьк)

\title{
МЕДИЧНИЙ ДИСКУРС ХУДОЖНЬОЇ ЛІТЕРАТУРИ
}

У статті досліджується медичний дискурс художньої літератури. Розглядається взаємодія медицини - мистецтва - літератури. Вивчається подвижницька прачя лікарівписьменників, аналізується їх творчість, окрема увага сконщентрована на постатях украӥнських письменників, які відображали образ лікаря в творчості, самі були медиками за освітою тощо.

Ключові слова: медицина, лікар, письменник, художне слово, мистецька творчість.

В статье изучается медицинский дискурс художественной литературы. Рассматривается взаимодействие медицины - искусства - литературы. Изучается преданная работа врачей-писателей, анализируется их творчество, отдельное внимание сконцентрировано на деятельности украинских писателей, которые изображали образ врача в творчестве, сами были медиками по образованию.

Ключевые слова: медицина, врач, писатель, художественное слово, художественное творчество.

The article analyses the medical discourse of the fiction. The interaction of the medicine, art and literature is examined. The author studies the devoted work of the doctors-writers, analyses their creative work, gives special consideration to the work of the Ukrainian writers that depicted the doctor image in the creative work having a medical degree.

Key words: medicine, doctor, writer, work of fiction, art work.

У світі мало людей, які б не стикалися $з$ лікарями: спершу - 3 лагідними руками лікарки-акушерки, яка впускає дитину в життя; потім - допомога педіатра, який слідкує за станом здоров'я від народження до повноліття, і дай Боже, щоб на цьому знайомство з лікарями припинилося, однак... Навіть в останні дні життя людина потребує супроводу лікарів.

Цікавий факт, що в далекому минулому лікареві дозволялося здійснювати медичну діяльність лише у випадку отримання ступеня бакалавра мистецтв. Тому не випадково багато медиків звертаються до мистецтва, зокрема живопису, скульптури, фотографії тощо. I цьому $є$ пояснення: лікарі часто втручаються, по суті, у справи Божі й буквально витягають людину 3 іншого світу. Розраду духовно-моральну знаходять вони у творчості, чому $є$ немало прикладів. Так, відомий лікар-художник, професор дантистки Т. Снігурович 
створив понад 250 національних ікон у стародавньому стилі. Долучився до мистецтва й О. Шевчукевич, талановитий лікар-скульптур 3 Буковини. Найбільше 3 хворими спілкуються медичні сестри й санітарки, які теж не полишають мистецьких уподобань і створюють картини із зерен рису, гречки, пшона та іншого збіжжя. Співчуття до фізично знедолених людей виразив Т. Шевченко в картині «Сліпа 3 дочкою», а художник І. Ковтонюк у картині «Сумні роздуми» відтворив образ М. Коцюбинського під час лікування в терапевтичній клініці В. Образцова.

Колись гуманітарна освіта для медика була обов’язковою умовою. I це не випадково, адже в основі цих двох галузей: медицини і літератури - Людина, цілісна, мисляча, страждаюча. В обох науках є і спільний засіб лікування Слово. Недаремно Гіппократ говорив: «Існує три типи лікарів. Один з них лікує травами, другий ножем, третій словом. То звернімося до того, хто лікує словом, адже лікуючи тіло, він лікує $і$ душу» [Афоризми, прислів'я, сентенції 2008:103].

Отже, художня література є потужним «лікувально-оздоровлюючим» засобом, бо вчить співпереживати героям, зумовлює катарсис i очищення почуттів, духовно підтримує моральний і фізичний стан читача.

По праву письменники-лікарі $\epsilon$ елітою літературного жанру. Згадаймо М. Булгакова (випускник медичного факультету Київського університету Св. Володимира, набув досвід у військових шпиталях, працював приватно практикуючим венерологом), Остапа Вишню (Павло Губенко закінчив Київську військово-фельдшерську школу, десять років працював за спеціальністю) та багатьох інших, що лікували словом душу й тіло.

Відомий гуморист Остап Вишня 3 метою запобігання шарлатанству написав фейлетон «Ох і лікували нас» про пасічанську шептуху Палажку, яка нагадує численних знахарок. Після цієї публікації люди стали обходити таких «народних зцілителів», зверталися до дипломованих лікарів. Спеціальність знадобилася i в таборах, коли він безпомилково ставив правильний діагноз i виявляв симулянта, що хотів уникнути роботи. Остап Вишня ніколи не 
розлучався з фельдшерським довідником, що був його постійним порадником.

У роки навчання в Київському медичному інституті розпочав літературну діяльність В. Коротич. П. Бейлін прийшов в українську літературу, об’єднавши всю творчість у книжці «Поговори со мною, доктор!». Помітний внесок у драматургію 20-30-х pp. XX ст. зробив I. Микитенко (Петро Бунь, Незаможник, Андрій Похмурий - псевдоніми. - прим. нама. - В.П.), який, закінчивши Херсонське військово-фельдшерське училище, брав участь у боротьбі з тифом у селах Єлисаветградщини, поєднуючи лікарську практику з письменницькою діяльністю. Одним із перших, хто зрозумів масштаби Чорнобильської трагедії, був Ю. Щербак (лікар-епідеміолог), який пізніше став засновником екологічного руху в Україні. За його творами знято відомі фільми.

Очевидно, саме тому лікарі за фахом, які стали письменниками, так майстерно й переконливо створили образи медиків і хворих у художніх творах. Згадаймо Л. Толстого і І. Тургенєва, В. Вересаєва і Г. Флобера (Гюстав Флобер народився і виховувався в родині лікарів і з раннього дитинства бачив перипетії життя лікарів, через що листи його просто насичені медичними темами. - прим. нама. - В.П.), А. Чехова і О’Генрі, А. Конан-Дойля і С. Моема, В. Стефаника і С. Руданського...

Плеяда медиків-письменників безкінечна як і Всесвіт, а твори залишили помітний слід у медичній деонтологіі (наука про обов'язок лікаря, його взаємовідносини 3 хворим. - прим. нама. - В.П.). Дивовижні таємниці психології хворої людини відкриваються в художніх полотнах Л. Толстого й А. Чехова, глибокі психологічні колізії розкрито Г. Діккенсом, а романи Ф. Достоєвського до сьогодні залишаються практичним посібником для медиків з психоневрологіi.

Наукова фантастика також присутня в медичній тематиці. Видатний лікар М. Амосов у повісті «Записки 3 майбутнього» (1966) описує анабіозобезсмертення людини.

Образ лікаря 3 давніх-давен оспівувався в літературі. Починаючи 3 часів Гомера, візантійської поетеси Феосовії та інших і до наших днів зберігається 
інтерес митців до можливостей відтворення його потужної моральної сили. Образами самовідданих лікарів насичена класична література. Наприклад, простим і великим, справжнім героєм є доктор Димов з оповідання А. Чехова «Попрыгунья».

Проте і непрофесіональний лікар ставав прообразом літературних героїв. Варто згадати творчу спадщину Буало, Рабле та ін. Крім справжнього лікаря, на жаль, траплялися і шарлатани, і особи, які вбачали у своїй професії лише факт матеріального забезпечення. Часто доводилося мати справу 3 лікарями Мольєру, хворому на туберкульоз. Він висміював їх у творах за спекуляцію, незнання сутності хвороби, хибні діагнози. Безжально зривали маски з лікарів свого часу Л. Толстой («Анна Каренина»), О. Горький, А. Чехов («Палата № 6»). Так, у повісті «Цветы запоздалые» змальовує митець типовий образ приватного лікаря кінця ХIX ст. - Топоркова. Не обійшов цю тему й М. Салтиков-Щедрін. Лікар-гуманіст В. Вересаєв у «Записках врача» описує постановку медичної справи в Росії, М. Булгаков у «Записках юного врача», зокрема оповіданні «Тьма египетская», 3 гіркою іронією пише про неуцтво медиків.

Заслуговує уваги медичний дискурс і в українській літературі. Відомий лікар душі і тіла Модест Левицький здобув другу медичну освіту лише 3 єдиною метою - врятувати хвору на сухоти дружину і стати «мужицьким дохтуром». Крім майстра літературної праці, людство здобуло в його собі й невтомного лікаря-новатора. У віці 27 років земський лікар розпочинає практику в м. Ковелі, де відбулося й доленосне знайомство з родиною Косачів. Маючи свідому національно-патріотичну позицію, він у спілкуванні 3 освіченою родиною і сам морально й професійно зростав. У 1895 р. під час спалаху холери в краї М. Левицький поселяє дружину з сином під опіку Олени Пчілки. Пройнятий недугами Лесі Українки i дружини завжди був для них безвідмовним рятівником. Розуміючи занедбаний стан медицини, неосвіченість народу, відсутність санітарно-гігієнічних норм, лікар розпочинає публіцистичну діяльність 3 метою профілактики здорового способу життя. 
I хоча стан хворої дружини, який постійно погіршувався, спричиняв часті переїзди, М. Левицький не полишав художньої творчості, брався до перекладацької роботи (разом 3 дружиною перекладали твори Е. Сінклера, Г. Сенкевіча українською. - прим. нама. - В.П.), регулярно видавав науковопопулярні матеріали на медичну тему.

Гідне прикладу життя Степана Руданського - письменника, який висміяв у творах несправедливість тогочасного суспільства, і лікаря, який безкоштовно лікував бідних і був заступником їхніх інтересів. Після закінчення семінарії, усупереч волі батьків, С. Руданський вступає до Петербурзької медикохірургічної академії, бо вбачає своє призначення в дієвій допомозі людям. Саме в академії відбулося становлення Руданського-поета: знайомство 3 Т. Шевченком, який повернувся із заслання, участь у напруженому громадськополітичному та літературно-науковому житті, друкування перших творів у журналі «Основа». Голодне студентське життя призвело до загострення туберкульозу. Здібного дипломованого лікаря медицини лікував відомий професор С. Боткін, який за сприянням академії допоміг С. Руданському отримати посаду міського лікаря в Криму в м. Ялта. Матеріальне становище було настільки скрутним, що в лікаря Руданського не було коштів доїхати 3 Сімферополя до Ялти. Прибувши на місце призначення, побачив, наскільки мізерним $є$ медичне облаштування клініки: для тисячного міста - п’ять ліжок. Це ж - ніщо. С. Руданський був здивований незадовільним станом приміщення, харчуванням хворих, відсутністю медичних інструментів й недостатнім постачанням ліків, наполягав на необхідності збирання фахової літератури. У той же час така зухвалість не подобалася місцевому керівництву, до того ж завзятість молодого спеціаліста, самовідданість справі, високий професіоналізм поширювали славу про нього по всьому узбережжю. Бажання нового лікаря зробити щось корисне для міста було настільки сильним, що він став купувати медичну літературу на свою мізерну зарплату (це і стало основою першої медичної бібліотеки на Південному березі. - прим. нама. - В.П.). Спостерігаючи за плином хвороб місцевих жителів, лікар почав вивчати та 
систематизувати явища природи, лікувальні властивості клімату й морської води, своїми силами відкрив на території лікарні перший метеорологічний пункт, заклав наукові підвалини кліматології. С. Руданського по праву вважають піонером вітчизняної кліматотерапії.

Влітку 1872 р. в Криму вирувала епідемія холери, яка поширювалась безупинно. С. Руданського на громадських засадах було призначено карантинним лікарем і постійним членом міської санітарної комісії. Слабке здоров’я, рятування хворих спричинили хворобу самого лікаря. Пролежавши в ліжку дев’ять місяців, поет і лікар помер. Пацієнти С. Руданського відзначали: гарний був лікар - займаючись приватною лікарською практикою, ніколи не брав матеріальної винагороди, а часто ще й сам допомагав грошима, за власні кошти їздив по всьому узбережжю, часто залишаючись голодним. I до того ж, саме в Ялті розпочав переклад творів Гомера українською.

В українській літературі ХХ ст. також є чимало художніх творів, де колізія сюжету пов’язана 3 образами лікарів. Подвижницьке життя лікаря Олександра Постоловського в Узбекистані змальовано Б. АнтоненкомДавидовичем у романі «За ширмою». Перед читачем постає висококваліфікований спеціаліст, енергійний, вольовий, ініціативний, який, крім основної роботи, багато уваги приділяє науковим дослідженням і мріє про відкриття в медицині та публікацію результатів проведених експериментів. Постійно думаючи про покращення медичного обслуговування, добився відбудови лікарні, стовідсоткового опалення взимку; працюючи дільничним лікарем, зменшив кількість хворих на малярію, а головною своєю перемогою вважав будівництво пологового будинку. Однак майстерність письменницького задуму виявилася у змалюванні протиріччя дзеркального образу лікаря. Чуйний, самовідданий на службі, він злочинно недбалий до найдорожчої людини в житті - матері, Одарки Пилипівни. Рідний син прогледів і не надав допомоги, щоб врятувати або хоча б полегшити останні дні невиліковно хворої жінки. 
Змістовним (а отже цінним для читачів, а, можливо, й медиків) є опис протікання раку, який у радянські часи був малодослідженим, не так поширеним, як потім 3 бурхливим розвитком промисловості, тому й ефективних засобів лікування не існувало, медичні пошуки ліків тільки починалися.

«Рак! Підступна, зловісна хвороба...

Тихо, часто без болю, без помітних зовнішніх ознак попервах, вона міцзно хапає своӥми иупкими пазурами якийсь орган людини й без жалю руйнує його. Та цุього їй мало. Ї̈ спрага нищчити - невситима! I вона по лімфатичних путях розпросторюється далі, засилає в ближчі цे дальні органи свої нищзівні, диверсійні десанти - метастази.

I ось дужий досі організм, іноді саме в розквіті сил, раптом, мов підтята в корінні рослина, - підтята нииком, крадькома, десь у глибині грунту, починає занепадати, в'янути, всихати. Хвору людину охоплює загальна кволість, утома, недокрів'я, людина марніє, обличчя ї̈ набирає неприємного землистого кольору, сохне шкіра... А там, у тканинах ураженого органа, невпинно точиться страшна робота руйнації. Ракова пухлина росте, збільшується, - ï клітини, изі мікровелетні-напасники, бурхливо множаться й ширяться. Мов хижаки, вони вдираються в суміжні міжтканеві щзілини, руйнують здорову тканину й вкорінюються; $і$ нема їм спину, і нема пощади ні життєво важливим органам людини, ні самому людському життю.

Та ось пухлина розпадається, розкриваються зруйновані кровоносні судини, - i нараз починається тяжка ракова кровотеча. I людське життя стає під страшну загрозу: кровотеча може перетнути його...

Хворій людині, знесиленій від великої крововтрати, може навіть на якийсь час полегшати, їй раптом починає здаватись, ніби хвороба вичерпала саму себе і ось уже кінецьь їи, за яким почнеться одужання...

Нужденна омана!

Леле, це не кінецьь хвороби, не поразка ї̈, навіть не тимчасовий, змушений відстуn, изе - ї̈ перша велика перемога! Її нездоланний дух нищення й загибелі 
вже прорвався далі по організму, розсипався загонами смерті, і хто зна, може, вже не в одному, а в кількох місиях росте нова злоякісна пухлина, вдирається в нові тканини й нищ̧ить, нищ̧ить...

I отак до нового розпаду пухлини, до нової кровотечі, до той останньої поразки, коли, нарешті, сили життя капітулюють перед силою смерті...» [Антоненко-Давидович 1999:625].

Образ іншого, відданого людині, лікаря змальовано О. Довженком в оповіданні «Воля до життя». В основі твору лежить реальний факт: «головний військовий хірург 38 армї Микола Омелянович Дудко (чоловік сестри Поліни Петрівни) під час війни на станщуї Куп'янськ Харківської обл. оперував важко пораненого солдата. Гангрена швидко поширювалася, $і$ лікарі визнали його стан безнадійним. Після медичного обходу хворий, зібравии останні сили, увірвався до операційної $i$ вимагав зробити йому операцฺюю. Тоді й застосував О. Дудко винайдену ним протигангренозну сироватку. Життя воїна було врятовано. Зустрівшись невдовзі після звільнення Орла від фашистів $з$ Довженком, він розповів йому про цей випадок. Схвильований почутим, письменник і створив своє відоме оповідання»[Лікує слово 1999:5]. Необхідно зважити, що лікар на війні - це особлива людина, яка крім специфіки обставин постійно межує 3 життям і смертю людей. Таким постає і хірург, який на обході бачить безнадійно хворого воїна, але все ж таки дарує йому хвилину надії, бо «Людина на війні - цее воля. С воля - є людина! Нема волі - нема людини!» [Довженко 1989:115]. Хворий Кармалюк неначе зрозумів підтекст відповіді жити! Тому й із останніх сил вривається до перев’язочної і вимагає медичної допомоги. Саме воля до життя врятувала його, бо дивлячись на таку поведінку хворого, і стомлений від тисяч операцій лікар відроджується за роботою: «Хірург праџюював з надзвичайним натхненням і любов’ю. Ніколи щзе не хотілось йому так палко врятувати життя людини, як зараз. Іван лежав перед ним у глибокій нестямі, але його могутня воля до життя передалась лікареві $i$ сповнила його вщерть. Він забув свою втому, свої безсонні ночі $і$ працюювв, як після живодайного сну $і$ освіжної ванни, пращуював легко й радісно, $і$ сонще, щуо 
зазирнуло було на хвилинку з-за хмар в операчійну, мов усміхнулось йому, наче обіиянка щуастя. Так сила опору смерті помножила силу лікаря, і июю силу лікар вертав хворому» [Довженко 1989:123].

Отже, медичний дискурс художньої літератури представлений у плеяді світового письменства і видатними українськими митцями, які були за фаховою освітою лікарями і мали в професії довготривалий практичний досвід. Творчий здобуток вітчизняних письменників, які створили образи лікарів, розкрили не лише моральний потенціал людей цієї професії, але й пов'язану 3 ним специфіку відповідальності за людське життя, що супроводжує професію лікаря, може стати, на нашу думку, об'єктом окремих наукових досліджень.

\section{БІБЛІОГРАФІЯ}

Антоненко-Давидович 1999 - Антоненко-Давидович Б. Твори: В 2-х т.Т. 1 : Повісті та романи / Б.Антоненко-Давидович. - К. : Наукова думка, 1999. $744 \mathrm{c}$.

Афоризми, прислів'я, сентенції 2008:103 - Афоризми, прислів'я, сентенції про лікарів // Медичне право. - 2008. - № 2. - С. 103.

Довженко 1989 - Довженко О. Твори / О.Довженко. - К. : Наукова думка, 1989. -235 c.

Лікує слово 1999 - Лікує слово. Проблеми медичної деонтології в художній літературі. - Київ, 1999. - 265с. 